\title{
Cultural Introduction in College English Teaching
}

\author{
Ying Wei \\ Foreign Language School \\ Huanghe Science and Technology University \\ Zhengzhou, Henan \\ e-mail: candy_weiying@yeah.net
}

\begin{abstract}
Language carries culture, and culture lays the foundation for language. Both of them closely co-exist and interact. But due attention has not been given to cultural elements in English teaching in China- neither systematic nor comprehensive. Such a situation has resulted in poor command of relevant cultures on the part of the student, especially their communicative competence. It's quite necessary to introduce culture background in college English teaching with the aim of improving students' accurate and fluent English both in and outside classes. Based on many years' English teaching, the author puts forward several principles and methods to integrate cultural elements in college English teaching, with the aim of developing learner's language competence.
\end{abstract}

\section{Keywords -culture; English teaching; principles; methods}

\section{INTRODUCTION}

Globalization facilitating people's communication around the world, English- as the most widely used language, develops into an ideal international communicative tool. Undoubtedly, good oral English ability is beneficial to international communication. For Chinese college students, they have devoted a tremendous wealth of time and energy to improve English, but the result is unsatisfactory: they partially can obtain high marks in English exams, but quite a number of them are incapable of speaking proper English even though they might read and write. It is most probably due to the environment where we study English, including outside cultural environment (in Chinese-speaking country) and learners' mental environment (e.g. thinking and action mode restrained by Chinese culture). The complex impact of the two environments has determined the unique features of learning English in China: it is only regarded as a required course, rather than a communication tool. Actually, the primary goal of learning English is to integrate the two cultures, to accept and absorb English elements, and then acquire the bilingual capability and maintain social relations among people. So, it is of vital importance for English teachers to cultivate students' competence to use English accurately and appropriately, that is to say students not only master linguistic ability (e.g. pronunciation, vocabulary and grammar...), but also grasp cultural ability (e.g. using it in an appropriate situation, like native-speakers).

\section{LANGUAGE, CULTURE AND INTERCULTURAL COMMUNICATION}

\section{A. Language and Culture}

Smith once noted: "Whenever people interact they communicate. To live in societies and to maintain their culture they have to communicate." (Samovar, Porter \& Stefani, 2000:22) He has revealed the fact that language is a system of symbols serving for human social communication and the carrier of culture which embodies the cultural elements. Culture consists of all the shared products of human society, which means not only material things such as buildings, cities, organizations etc., but also non- material things such as ideas, customs, language etc.

Generally speaking, culture refers to the whole aspects of people's social life. Of which language is an essential part. Some social scientists regard it as the footstone of culture. Without language, culture is just like unrooted trees; while language is deeply influenced and shaded by culture. In a broad sense, language is the symbolic representation of historical and culture background of human beings as well as people's mental and physical actions.

\section{B. Intercultural Communication}

The publication of Edward T. Hall's The Silent Language in 1959 marked the birth of the conceptions of intercultural communication as an independent discipline. Since then, scholars from various linguistic backgrounds have shifted their focus to the cultural aspect and made a great contribution to its development. They also stressed that communicative competence should not only contain linguistic forms of language, but the social-cultural rules as well.

Professor $\mathrm{Hu}$ Wenzhong once pointed out learning a language should develop two competences: linguistic competence and social competence. Linguistic competence is the knowledge of what words mean, how they are put together to form sentences and how they are pronounced; while social competence, we can call it cross-cultural competence, refers to an ability to interact effectively with people of different cultures.

With the globalization, intercultural communications have been more frequently conducted than ever before, which occurs whenever a message is produced by a member 
of one culture understood by a member of another culture. Culture is largely responsible for the construction of our individual social reality and for our individual communicative behaviors. What's more, the technological development in transportation and communication further helps today's people to be more mobile and more likely to encounter with peoples of different linguistic and cultural backgrounds. Therefore, an ability to communicate effectively in a language other than one's mother tongue has become a valuable asset in our society.

\section{Significance of Cultural Introduction in English Teaching}

As we know, among five English skills (listening, speaking, reading, writing, translating), speaking is normally considered as the most productive or creative skill. Acquiring this skill therefore seems to be more laborious and demanding. The common phenomenon is that having studied English for 15 to 20 years, quite a number of college students simply can't speak proper English though they might read and write. After many years of English learning, students feel that the traditional English teaching model that concentrates on the five basic language skills (listening, speaking, reading, writing and translation) cannot cater for their requirement. The truth is that one student can have a good linguistic competence; however his communicative competence is poor, so he can't speak or communicate with others in English. As we have mentioned above, the main task to learn a language is to communicate.

Traditional English teaching in China is teacher-centered, examination-oriented, grammar and vocabulary-based method. Knowledge of English is transmitted to students through teacher who acts as an authority, a knowledge-giver. Students are simply regarded as silent passive knowledge receivers. Nowadays it is a trend in language teaching to stress the importance of culture teaching and the impossibility to teach a language without teaching culture. It can be found that the cultural barrier is the big issue in the oral English practice. Certainly, it could not be denied that students were thus exposed to many cultural facts and practices different from their home culture. Foreign cultures may arouse their interest and passion in English learning. The comparison of native culture and foreign culture may help them understand their own culture and other cultures and even urge them to reflect on their own behaviors and ideas. Therefore culture introduction in the foreign language learning should be raised. English teachers should introduce and integrate English culture into classroom.

\section{PRINCIPLES OF CULTURAL INTRODUCTION IN ENGLISH TEACHING}

In non-English environment, due to the limitation of studying time and a lack of target language input, it is impossible for the English learners to acquire all the English elements only from the textbooks. We should keep it in mind that the aim of culture teaching is to improve students' communicative competence. Based on the above discussion, some principles are needed are as follows: the principle of sequence, the principle of life-like cultural environment, the principle of appropriateness, the principle of studentcentered oral class. The four principles in culture teaching may be incomplete. From the author's view, in some cases special emphasis is laid on one or two of the principles; while in other cases, the principles are used alternatively or altogether. It just depends on who the learners are or what the situation is.

\section{A. The Principle of Sequence}

As we know, any kind of teaching activity should go step by step with a scientific and reasonable sequence. Culture teaching is without exception. The input of cultural contents should be selected and arranged from the easy to the difficult, from surface to deep, matching the learner's cognitive procedure, linguistic competence, and the ability of acceptance and comprehension.

First of all, the contents of cultural introduction that teachers choose must be related to the textbooks and student's cognitive level; otherwise, the students may think that cultural teaching is too abstract, empty and unfathomable. In specifying objectives of cultural teaching, many socio-culturists hold that the overall goals are intercultural understanding and intercultural communication.

What's more, culture teaching can be implemented based on Hammerly's three levels of culture. It includes "information culture", "behavior culture" and "success culture". "Information culture" refers to native speakers' acknowledgements of the society, history, geography, heroes and so on, which Hammerly believed foreign language learners should learn about by any form. Hammerly regards "behavior culture" as people's actions (greeting, introducing others, inquiring, shopping, inviting etc.) plus their attitudes, values, worldview etc(view of time, view of friendship, view of aesthetics, racial outlook etc.). And he emphasizes "behavior culture" is the most important culture that foreign language learners should acquire. Let's take Unit 5, Book 1 of listening and speaking course of New Horizon College English as an example. When practicing the conversation of Model 1 (David interrupted Nancy again and again), teachers can explain to students that interrupting others to speak out one's own words is regarded as impolite in Chinese culture; while in English culture, people desire for creative opinions and welcome challenging ideas to pursue the best. This kind of cultural phenomenon can be demonstrated in conversations, they interrupt other's talk, spell out their own words directly or challenge other's opinions and so on. "Success culture" is traditionally seen as art or literature achievements, which students can acquire from the stimulation of foreign movies, novels or other art activities.

\section{B. The Principle of Life-like Cultural Environment}

Owing to the lack of cultural environment and language environment, English teachers should attempt to bring the students to a life-like environment, that is to say try to create good English surroundings and to make students feel like native learners talk with others in a real English cultural environment. Actually, in China the main form of English teaching is classroom. So, teachers can design some pictures on the wall with some culture topics, music or videos 
through multi-media devices to facilitate students feel western conditions and customs and attract their interest for English learning. At the same time teachers can cultivate students to think, to speak, to write in English way, for example encourage them to answer questions, to describe what happened yesterday in English or create some situations for students to respond, to paraphrase a few sentences or to retell a story etc. And an important thing should not be neglected: teachers had better not disrupt them to correct students' errors when they attempt to say or write in English; the best way is to give them an inspiring judgment to make them have a successful feeling of getting knowledge. Then they will be glad to speak it more and more and their practical English are effectively trained. Obviously in such a lively atmosphere, students have been motivated to convey their ideas in English.

\section{The Principle of Appropriateness}

This principle requires that imparting language knowledge and developing language skills are still the main objective of English teaching. Cultural education, not the central part of language teaching, should be carried out in the frame of language teaching with the purpose of helping students master language points and communicative skills. Otherwise, prattle on cultural background and cultural differences are putting the cart before the horse. Besides, this principle requires teachers pay attention to the student's psychology. Psychological qualities are essential to language learning. Ignoring non-intellectual factors can be obstructive in language learning, especially in speaking a foreign language. For interaction activities, it requires students appreciate their own uniqueness, not manipulated, directed or decided by the teacher as to how they learn, but encouraged to build up self-confidence and enjoyment in English learning.

\section{The Principle of Student-centered Class}

With the development of humanistic psychology, the class tends to be no longer teacher-centered, examinationcentered but learner-centered and learning-centered especially in oral class. If students are the actors, the teacher is a director, conductor, scriptwriter, audience, or commentator. It is the teacher's responsibility to organize the classroom as a platform for oral interactive activities. But in fact, a great deal of typical classroom interaction is initiated by teacher's questions, directions, information and students have been used to "speak only when asked to". The right way is to give students opportunities to initiate oral communication. What's more, the teacher acts as a motivator. Try to appeal to students' interests with the supply of intercultural knowledge, that is to say, students should be intrinsically motivated into the speaking task. In class, teachers are expected to accept all kinds of opinions, and be tolerant of errors the students make while attempting to communicate, because interactive language teaching requires a high degree of indirect leadership, emotional maturity, perceptiveness, and sensitivity to others' feelings. When teachers demonstrate these qualities, students lose their fear and embarrassment to express themselves, to show what they can do, to propose and participate in activities because they feel appreciated and valued.

\section{THE METHODS OF CULTURAL INTRODUCTION IN ORAL ENGLISH TEACHING}

Now that the aim of language teaching is to help students acquire communicative competence. With the new technology in communication and education we can now go further. Great importance teaching has been attached to the scholars interested in Chinese national college English reform. As a result, the discussion on the topic of intercultural communication introduction into classroom teaching has already become rather popular in Chinese language teaching field. However, in language teaching, teachers often find themselves in a dilemma as Stern once stated (1999:191): "if they concentrate too hard on linguistic forms and forget the people who use the forms in ordinary communication, they distort the reality of language use; on the other hand, if they overemphasize people and country and disregard the details of linguistic forms their teaching tends to become superficial and unserviceable". Though some teachers involve culture information in language classrooms unsolicited, culture teaching is still confined to isolated items and background information. This part will deal with this unsettled question: how could culture be introduced into oral English teaching? Some methods will be listed as a reference.

\section{A. Textbooks Method}

Textbooks play a crucial role in English learning. Its content and the teaching objectives reflected in it do affect the actual teaching practice. Textbooks are a stimulus or instrument for language teaching and learning. Graves (2005) makes an analogy between a textbook and a piano by saying that as teachers, who are called on to be not only musicians to produce music, but also piano tuners, composers and conductors. In other words, textbooks can be and should be adapted in practice.

Textbook is one of the major functioning carriers of the target culture in the current mode of intercultural communication. Learners are required to read as much as possible the cultural elements stuffed in all kinds of texts. However, the current prevailing textbooks in spoken English teaching class deal little with the culture learning as well as the skills in intercultural communication, so teachers taking advantage of textbook to infuse the culture might as well search for supplemented culture information to enrich the content of textbooks and to encourage students say more about the topics of textbooks.

\section{B. Practice Method}

Listening, speaking, reading and writing are integrated skills in English learning. The practice method enhances the focus on practical communication, which is essential in developing students' competence in oral English. We can identify two ways of integrating skills: simple integration--a receptive language skills (listening \& speaking) serves as a model for a productive language skills (reading \& writing); 
and complex integration--a combination of activities involving different skills. These involve constructing a series of actives that use a variety of skills. It is agreed that receptive language skills (input) plays a critical role in language acquisition. As far as speaking is concerned, without input the learner has nothing to say. But the question is what kind, form, and amount of input is most useful for students. When teachers design teaching materials or organize classroom activities, such as English corners, debate competition, English drama etc., they should give thought to giving their students enough comprehensible input, that is to say teachers can introduce some cultural background information, idioms, and traditions or invite the foreign teachers to illustrate some cultural phenomena to students). If students want to speak well and really integrate the foreign culture, listening and reading skills are necessary. These four skills should be separated and emphasized in the teaching process.

\section{Contrast Method}

The application of contrast method to English teaching is one of the important devices in cross-cultural teaching. Owing to the interactive relationship between language and culture, two languages are never completely equivalent. In English teaching, we tend to put more emphasis on the differences than on the similarities between Chinese and English. However, how people perceive other people is influenced by the degree of similarity perceived. Attention should therefore be drawn on cultural similarities as well as differences. If teachers can explore and show the similarities to learners, learners will be able to express the ideas specific to Chinese culture more idiomatically.

Through contrast students can have a cognitive awareness of cultural differences between the two languages. Making comparisons is perhaps one activity which may help Chinese learners of English to understand foreign cultures and their home culture as well. Since values, beliefs, and attitudes lie so deeply within a culture, they are so often taken for granted. Our openness to outside countries, many young Chinese is overwhelmed by the western culture. They are familiar with Valentine's Day and Christmas traditions from English movies. In order to help learners to make a proper judgment in value choosing, teachers should increase learner's cultural awareness of cultural differences in values and attitudes, and to help to explore the common value shared by oriental culture. For example, in oral class, teachers can organize students to make greeting dialogues in pairs, and then show them some dialogues that English people make, in order to make a comparison. It's common that there are more polite address, such as Mr. Wang, or Professor Li in dialogues made by Chinese students. Since Chinese prefer to use titles or polite address to show our respect. Instead, Englishmen tend to address others by calling their given names directly to show friendliness. What's more, "Where are you going", "Are you busy these days?" or "Have you had your breakfast?" often appear in Chinese students' dialogues, which are considered too private to inquire for westerners. Another example, "the lady went up the aisle with one man and came back with another" suggests a western wedding tradition: the bride accompanied by her father is entrusted to the broom when arriving before the priest. Readers may misunderstand it as the bride's husband has changed without the cultural background. What's more, Chinese people value modesty and collectivism while westerners emphasize privacy, individualism and independence. These values can be found in literature works. Teachers can make full use of textbooks if the textbooks can provide English versions of Chinese classics.

By comparing the two cultures, students can be more aware of the different values. They can learn to respect other values while culture conflicts occur. And at the same time, a better understanding of the both culture helps to make a reasonable judgment when it comes to value choosing for them. They become more tolerant, open-minded and confident in English communication. What's more important, they have more effective English language acquisition.

\section{Teacher's Implantation}

Teachers, as the resources-providers, are the critical role of instruction materials. The cultural introduction in the class can't ignore the teacher's implantation. Cultural knowledge must be planned as carefully as their language counterparts and be included in lesson plans. To assure the presence of foreign cultural awareness in the curriculum, class should include specific culture objectives along with suggestions for introducing and practicing it. The objectives should be as clear as possible so that students know the "why" of what they are doing. In cultural learning activity, the teacher should find an opportunity to restate the objective, and demand the students make an assessment of whether you have achieved the objective. Language is an important carriage of culture. There are close links between them, when you learn language, you must know some knowledge about culture, and then you can understand and express some meaning correctly. In order to foster a more acute cultural mind-set, teachers are supposed to increase students' attention to cultural information.

In order to provide opportunities for life-like and meaningful communication in English classroom, learners' life experiences and their interest must be taken into consideration. Teacher can design some interactive activities which should be taken to deepening understanding of the target culture. The high-technology of IT industry has made it possible for language learners to watch the latest movies, videos and plays in original version of the target culture, so these cultural materials can be adopted properly by teacher. Besides enjoying the performance of the actors and actresses, the students can observe details of everyday situations, in case of greeting, farewell, compliments, apology, asking directions, shopping and debating, quarreling. They can learn from western's traditions, etiquette, means to solve conflicts, techniques of negotiation, debates, ways of showing love, dating, body language, as well as morality, religion and values, etc. 


\section{CONCLUSION}

With the development of intercultural communication, China needs a lot of competent language users. However, in schools, students' communicative competence is far from expectation which can't meet the needs of society. This phenomenon is caused by various reasons, but the lack of the intercultural knowledge is a neglected factor which is crucial to develop the students' speaking ability.

This thesis has attempted to draw the attention to culture introduction to college English teaching. The theory of intercultural culture and language tells us why teachers should lay emphasis on culture teaching. Furthermore, several principles and methods on how to integrate culture to oral English are provided to teachers as a reference. It is hoped that the issues discussed in this dissertation can bring some favorable ideas to the current college English teaching and lay the foundation for student's overall development.

\section{REFERENCES}

[1] Hymes. D. On Communicative Competence [C]. Sociolinguistics. Harmondsworth: Penguin, 1972

[2] Chn Guanglei. Culture Infusion in Language Teaching[J]. Language Teaching and Language Studies, 1992 (3).

[3] Dai Weidong. A New Concise Course on Linguistics of Students of English [M]. Shanghai: Shanghai foreign language Education Press, 2002.

[4] Hu Wenzhong. Culture and Communication[M].Foreign Language Teaching and Research Press, 1994.

[5] Guo Huiru, Cao Cheng. Cultural Input and English Teaching[J]. Journal of Yanan University, 2005(6).

[6] Wang Qiang. A Course in English Language Teaching [M]. Beijing: High Education Press, 2002. 